Article

\title{
Sewage Sludge as a Soil Amendment for Growing Biomass Plant Arundo donax L.
}

\author{
Marcela Gubišová ${ }^{1, *}$, Miroslav Horník ${ }^{2}$, Katarína Hrčková ${ }^{1}$, Jozef Gubiš ${ }^{1}$, Andrea Jakubcová ${ }^{2}$, \\ Martina Hudcovicová ${ }^{1}$ and Katarína Ondreičková ${ }^{1}$ (D) \\ 1 National Agricultural and Food Centre, Research Institute of Plant Production, Bratislavská cesta 122, \\ 92168 Piešt'any, Slovakia; katarina.hrckova@nppc.sk (K.H.); jozef.gubis@nppc.sk (J.G.); \\ martina.hudcovicova@nppc.sk (M.H.); katarina.ondreickova@nppc.sk (K.O.) \\ 2 Faculty of Natural Sciences, University of Ss. Cyril and Methodius in Trnava, Námestie J. Herdu 2, \\ 91701 Trnava, Slovakia; jakubcovaandrea@gmail.com (A.J.); miroslav.hornik@ucm.sk (M.H.) \\ * Correspondence: marcela.gubisova@nppc.sk; Tel.: +421-337-947-154
}

Received: 12 April 2020; Accepted: 7 May 2020; Published: 11 May 2020

\begin{abstract}
Sewage sludge (SS) is a waste originated from wastewater treatment that could be considered an interesting source of organic matter and nutrients for agricultural production. Our experiments aimed to assess the effect of SS on the growth parameters and the biomass yield of giant reed (Arundo donax L.) plants. Experiments were carried out in pots during two growing seasons, where samples of dried SS were applied in doses of 5 or $15 \mathrm{tha}^{-1}$. The number of shoots per plant was significantly higher with the application of $5 \mathrm{t} \mathrm{ha}^{-1}$ of SS into arable soil compared to the control treatment and did not increase with the dose of SS. On the other hand, the height of the plants was gradually elevated with the dose of SS. The diameter of the shoots was positively affected by the dose of $15 \mathrm{tha}^{-1}$, and it was the only parameter with significant differences between the used types of SS. The biomass yield increased by 1.2-2.7× depending on the type and dose of SS. Cu and $\mathrm{Zn}$ uptake, as micronutrients present in SS, and their accumulation in the aboveground parts were significantly higher for plants cultivated in the presence of SS.
\end{abstract}

Keywords: biomass yield; giant reed; growth parameters; potential toxic elements; sewage sludge

\section{Introduction}

Sewage sludge (SS) is defined as a semi-solid residual product arising from the wastewater treatment process in wastewater treatment plants. Due to its increasing amount, there exists a worldwide problem with its disposal. SS can be utilized as a raw material for industrial and energy production or as a soil amendment [1]. The application of SS in agriculture within the EU is currently regulated by the Council Directive 86/278/EEC, that specifies the limits of potential toxic elements (PTE) content. In the Slovak Republic, the criteria defined by the Act No. 188/2003 Z.z. must also be met before its application in agricultural land. The annual production of SS in the Slovak Republic within the years 2006-2017 was in the range of 53 to 59 thousand tons, but its direct application into the agricultural soils was negligible. From the total production of 54.5 thousand tons in 2017 (the latest available data), 24.6 tons were composted, 7.9 thousand tons were disposed of in landfills and 12.2 thousand tons were used for incineration [2].

The high content of organic matter and nutrients makes composted SS a useful amendment, that can improve the physical (water retention, soil texture, bulk density and soil porosity), chemical and biological properties of agricultural soils [3]. Due to the rising human population, the world demand for mineral fertilizers, mainly NPK, is increasing. Additionally, phosphate rocks, as the main source of phosphorus, are non-renewable, and there is the risk of its depletion [4]. SS generally 
contains significant amounts of $\mathrm{N}$ and P. By anaerobic digestion of wastewater sludge, organic $\mathrm{N}$ from proteins, amino acids and urea present in SS is converted to ammonia-nitrogen [5] that is readily available to plants. Along with the high content of N, SS represents a rich source of phosphorus that is predominantly presented in inorganic form [6]. Besides, organic matter in SS facilitates the bioavailability of important macro- and micronutrients and improves the soil structure [7]. Organic soil amendments promote plant growth not only directly, by improving the soil fertility, but also indirectly, by stimulating microbial growth in the rhizosphere [8].

However, the application of SS to the soil also entails certain risks that must be considered. Depending on the type of wastewater (municipal, industrial, combined), it may contain biological pollutants, high concentrations of some PTEs, especially Zn [9,10] and organic pollutants [11]. In addition to the soil contamination, many of them can be uptaken by plant roots and distributed in different plant organs, with the potential risk to contaminate the food chain. Although Vaca et al. [12] did not confirm higher PTE concentrations in corn grain after the application of $18 \mathrm{tha}^{-1}$ of SS compared to inorganic fertilizer, the opposite situation was observed in the experiments of Dar et al. [13]. They assessed the effect of SS on the growth of Brassica juncea L. cultivated in pots. These plants showed a strong ability to accumulate PTEs without any visible symptoms of toxicity. The addition of dried SS in a dose of $10-40 \%(w / w)$ increased the root and shoot length and the yield of plant biomass, but the content of $\mathrm{Zn}, \mathrm{Cd}$ and $\mathrm{Pb}$ in the plants exceeded the limits for human consumption. Similar results were observed for eggplant [14]. The plant height, root length and dry weight/yield were increased by the SS application at a dose of 50\%, but the cultivation of eggplant in the SS-amended soil led to the accumulation of PTEs, especially $\mathrm{Mn}, \mathrm{Cr}$ and $\mathrm{Cd}$, in the plants. Shahbazi et al. [15] also revealed the elevated concentration of PTEs in seeds of wheat plants grown in a soil treated with SS. The Cu level, in particular, was above the limits in both tested varieties of wheat.

Therefore, it seems more appropriate to recycle the valuable ingredients of SS to fertilize the soil intended for the cultivation of non-food crops. Several papers were published describing the application of SS into agricultural soils for the cultivation of energy crops. Lag-Brotons et al. [16] assessed different SS compost treatments for the productivity of Cynara cardunculus, in which the application of $50-70 \mathrm{tha}^{-1}$ had positive effects. The aboveground biomass yield increased by $68 \%$ and the seed and oil yield by $40 \%$. Wierbowska et al. [17] used SS to fertilize the soil for the growing of energy plants Virginia fanpetals. They compared the application of wet SS, dehydrated by pressing, and pelleted SS and observed that the plants of $V$. fanpetals utilized nitrogen and phosphorus more efficiently from wet SS than from its pelleted form. Kubátová et al. [18] observed the elevated yield of willows supported by SS fertilization from the second harvest, while the plant growth was limited in the first years. Several papers were published by the research group around Kołodziej and Antonkiewicz, which confirmed the positive effect of fertilization with SS on the biomass yield of energy plants from the Poaceae-Sorghum bicolor [19], Miscanthus $\times$ giganteus [20,21] and Phalaris arundinacea [21] families.

In our previous papers, samples of municipal SS were evaluated for the responses of rhizosphere bacterial [22] and fungal [23] communities to the application of SS into the soil. The present work aimed to assess the effect of SS on the growth parameters and the biomass yield of giant reed plants. Giant reed (Arundo donax L.) is a perennial rhizomatous grass from the Poaceae family that has been recognized as a promising energy plant, producing a huge amount of lignocellulosic biomass. This species is adaptable to different soil types and a wide range of $\mathrm{pH}$, tolerates salinized or contaminated soils and is a promising candidate for phytoremediation techniques [24,25]. Our hypothesis was that the addition of SS to the soil would increase the biomass production of A. donax plants. In this context, we compared two samples of SS originated from different sources. Moreover, the toxicological aspect of PTE accumulation in plants and the root-to-shoot translocation given by the presence of metals in SS samples was evaluated. 


\section{Materials and Methods}

Samples of anaerobically digested sewage sludge were obtained from two wastewater treatment plants: Pannon-Víz Plc., Győr, Hungary (marked as SSA), and Tavos, Inc., Piešt'any, Slovakia (marked as SSB). An element analysis of the SS samples (Table 1) by X-ray fluorescence spectrometry using the high-performance X-ray fluorescence spectrometer (X-LAB 2000, SPECTRO, Kleve, Germany) confirmed that the analysed metals did not exceed the limits permitted by the Act No. 188/2003 in the Slovak Republic. In the pot experiments, arable soil characterised as Luvi-Haplic Chernozem on loess with $\mathrm{pH}(\mathrm{KCl}) 6.3$ and medium content of humus was used. The content of macroelements in the SS samples and the soil is shown in Table 2. The total contents of $\mathrm{N}$ and $\mathrm{C}$ were determined according to the Dumas method using a CNS analyser (TruMac, LECO, St. Joseph, Michigan, USA). Other elements were measured by Microwave Plasma-Atomic Emission Spectroscopy (MP-AES 4100, Agilent, Santa Clara, California, USA) after their extraction from the samples by a Mehlich III solution and the microwave digestion of the extracts (system Ethos 1, Milestone, Sorisole, Italy).

Table 1. Content of potential toxic elements (PTEs) in sewage sludge (SS) samples.

\begin{tabular}{cccccccc}
\hline & \multicolumn{7}{c}{ PTEs [mg kg $\mathbf{~ k}^{-\mathbf{1}}$ d.w.] } \\
\hline Type of SS & As & Cd & Cr & Cu & Ni & Pb & Zn \\
\hline SSA & 8 & $<2$ & 85 & 654 & 42 & 36 & 1940 \\
SSB & 3 & $<1$ & 36 & 224 & 22 & 46 & 1269
\end{tabular}

SSA—anaerobically digested sewage sludge from wastewater treatment plant Pannon-Víz Plc., Győr, Hungary; SSB - anaerobically digested sewage sludge from wastewater treatment plant Tavos, Inc, Piešt'any, Slovakia; d.w.-dry weight.

Table 2. Content of macroelements in SS samples and soil.

\begin{tabular}{ccccccc}
\hline \multicolumn{7}{c}{ Macroelements [g kg $\mathbf{~} \mathbf{1}$ d.w.] } \\
\hline Substrate & N & C & Ca & Mg & K & P \\
\hline Soil & 0.958 & 10.3 & 2.94 & 0.280 & 0.193 & 0.097 \\
SSA & 34.7 & 564 & 23.7 & 5.70 & 5.96 & 18.1 \\
SSB & 35.1 & 334 & 36.4 & 6.44 & 2.66 & 16.7 \\
\hline
\end{tabular}

SSA - anaerobically digested sewage sludge from wastewater treatment plant Pannon-Víz Plc., Gyorr, Hungary; SSB - anaerobically digested sewage sludge from wastewater treatment plant Tavos, Inc, Piešt'any, Slovakia.

Pot experiments were carried out in two consecutive growing seasons, 2014 and 2015, with the application of SS samples (dried and mechanically homogenized to a fine powder)—SSA in 2014 and SSB in 2015. The pots were filled with $7 \mathrm{~kg}$ of arable soil (control) or soil supplemented with SSA or SSB in doses of 15.7 or $47.1 \mathrm{~g}$ of SS per pot (corresponding to the application of SS in doses of 5 or $15 \mathrm{tha}^{-1}$ ). The experiments were realized in ten replications for each treatment and type of SS.

The prepared substrate in the pots was thoroughly mixed and irrigated, and plants of giant reed (Arundo donax L.) were planted after one week. Young plants of giant reed originated from in vitro multiplication [26], and before the experiment the plants were acclimatised for 8 weeks under ex vitro conditions. Within the pot experiments, plants were grown under natural outdoor conditions from May to November. The experimental site was situated in a maize-growing region of western Slovakia (latitude $17^{\circ} 43^{\prime} 45^{\prime \prime} \mathrm{N}$, longitude $48^{\circ} 34^{\prime} 43^{\prime \prime} \mathrm{E}$, altitude $163 \mathrm{~m}$ ). The long-term sum of rainfall and average air temperature in the area is $595 \mathrm{~mm}$ and $9.2^{\circ} \mathrm{C}$ per year. The characteristics of the vegetation seasons of 2014 and 2015 are mentioned in Table 3.

The pots were placed in a completely randomised design and irrigated 3-5 times a week with 0.5-0.8 $\mathrm{L}$ of tap water per pot, depending on the plant stage and the weather conditions. To prevent nutrients leaching from pots, water-retaining plates were placed below each pot to collect and reuse the percolated water. Basic meteorological parameters were recorded daily from the point of view of 
precipitation, air temperature and growing degree days (Figure 1). Lower $\left(7^{\circ} \mathrm{C}\right)$ and upper $\left(30^{\circ} \mathrm{C}\right)$ thresholds for calculation of degree-days were used [27].

Table 3. Basic characterization of the vegetation seasons.

\begin{tabular}{cccccc}
\hline Season & Planting Date & Harvest & Vegetation Period & Precipitation & Average Air Temperature \\
\hline 2014 & 15.5 .2014 & 25.11 .2014 & 194 days & $660 \mathrm{~mm}$ & $11.81{ }^{\circ} \mathrm{C}$ \\
2015 & 18.5 .2015 & 13.11 .2015 & 179 days & $502 \mathrm{~mm}$ & $11.20^{\circ} \mathrm{C}$ \\
\hline
\end{tabular}

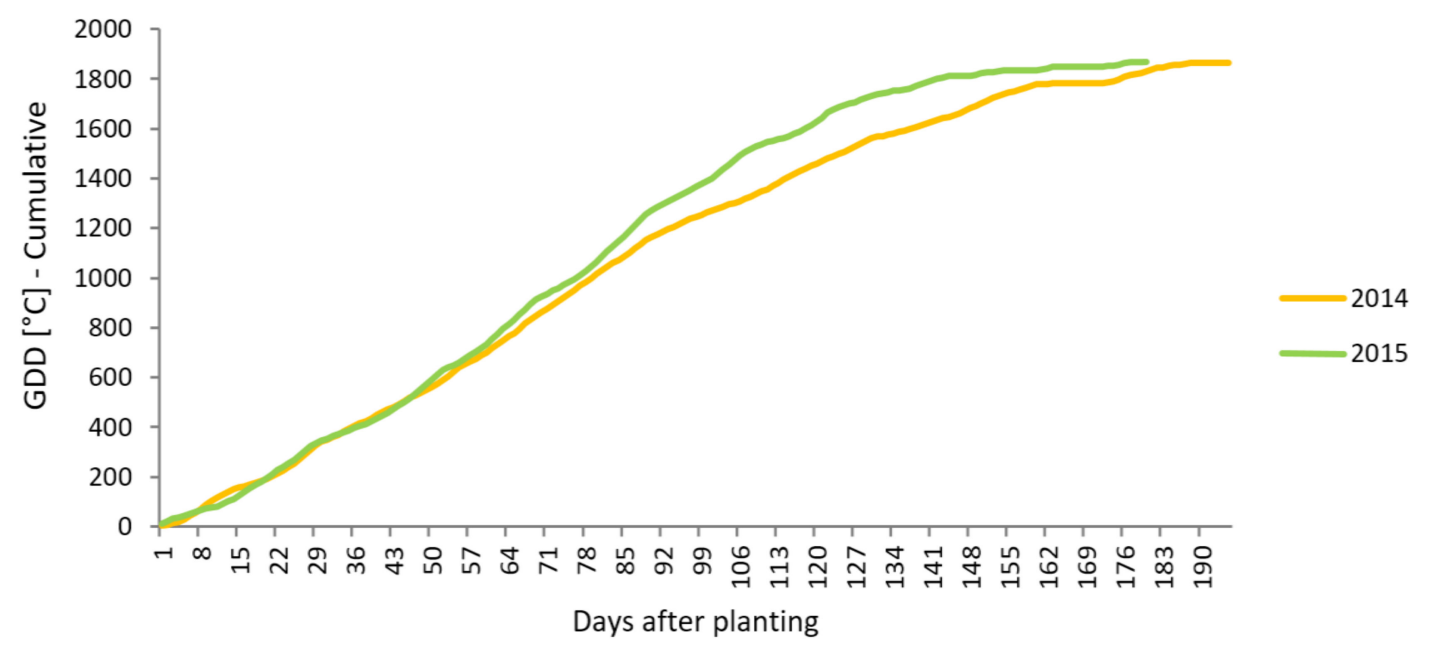

Figure 1. Curves of cumulative growing degree days (GDD) describing the vegetation seasons of 2014 and 2015.

Growth parameters-the number of shoots per plant, plant height and shoot diameter (the average height or shoot diameter of the two most developed shoots in July and three shoots in subsequent dates) -were measured monthly from July to October. At the end of the growing season, the growth parameters were measured on all shoots, together with the evaluation of the yield of dry biomass of the shoots and roots (for SSA treatment only). Nitrogen use efficiency (NUE) was calculated according to Foulkes \& Murchie [28], and the agronomic efficiency of applied $\mathrm{N}\left(\mathrm{AE}_{\mathrm{N}}\right)$ according to Cano-Ruiz et al. [29].

The accumulation and root-to-shoot translocation of $\mathrm{Cu}$ and $\mathrm{Zn}$ in the giant reed plants (in $\mathrm{mg} \mathrm{kg}^{-1}$; d.w. (dry matter)) were measured by atomic absorption spectrometry (AAS) using atomic absorption spectrometer iCE 3000 (Thermo Scientific, Waltham, Massachusetts, USA). Based on the estimated amount of metals in the samples, the determination was carried out either by flame atomization (acetylene/air; ppm amounts) or by electrothermal atomization (argon as an inert gas; ppb amounts).

Experimental data were analysed by ANOVA, and the means were separated by the LSD test (the least significant difference) at $\alpha=0.05$ using the statistical software STATGRAPHICS XVII-X64 (Statpoint Technologies, Inc., Warrenton, Virginia, USA).

\section{Results and Discussion}

The experiments were focused on the evaluation of the growth parameters (the number of shoots per plant, shoot height and shoot diameter) and the yield shoot and root biomass of giant reed (A. donax L.) plants cultivated in the arable soil without or with supplementation of two types of SS (SSA or SSB) in two doses (5 or $\left.15 \mathrm{tha}^{-1}\right)$.

\subsection{Plant Growth During the Vegetation Period}

The detailed monitoring of the plant growth during the vegetation season showed (Figure 2) that the number of shoots during the first experimental year increased practically continuously in the case 
of plants fertilized with SSA in both doses. Unfertilized plants did not have enough nutrients in the soil to perform well and to produce more shoots in comparison to fertilized plants during the entire vegetation period. The following season was characterized by slightly different growing conditions from the point of view of heat accumulation in the environment (Figure 1). A favourable warmer period in the first half of the vegetation season positively affected the formation of new shoots in all tested variants. Anyway, the fertilized plants showed better growth parameters in comparison to the unfertilized control group. The second half of the vegetation period was represented by colder conditions, and plants were not able to produce more new shoots-even in the case of groups fertilized with extra sources of nutrients. Spencer at al. [27] concluded that the shoot number of $A$. donax is a function of degree days, and the emergence of new shoots can be characterized and also predicted by the air temperature. Besides the development of new shoots, the growth of giant reed plants also involves the shoot height gain and shoot diameter thickening. All of these processes are closely connected. They take place together and represent the responses of the plants to the nutritional and environmental conditions.

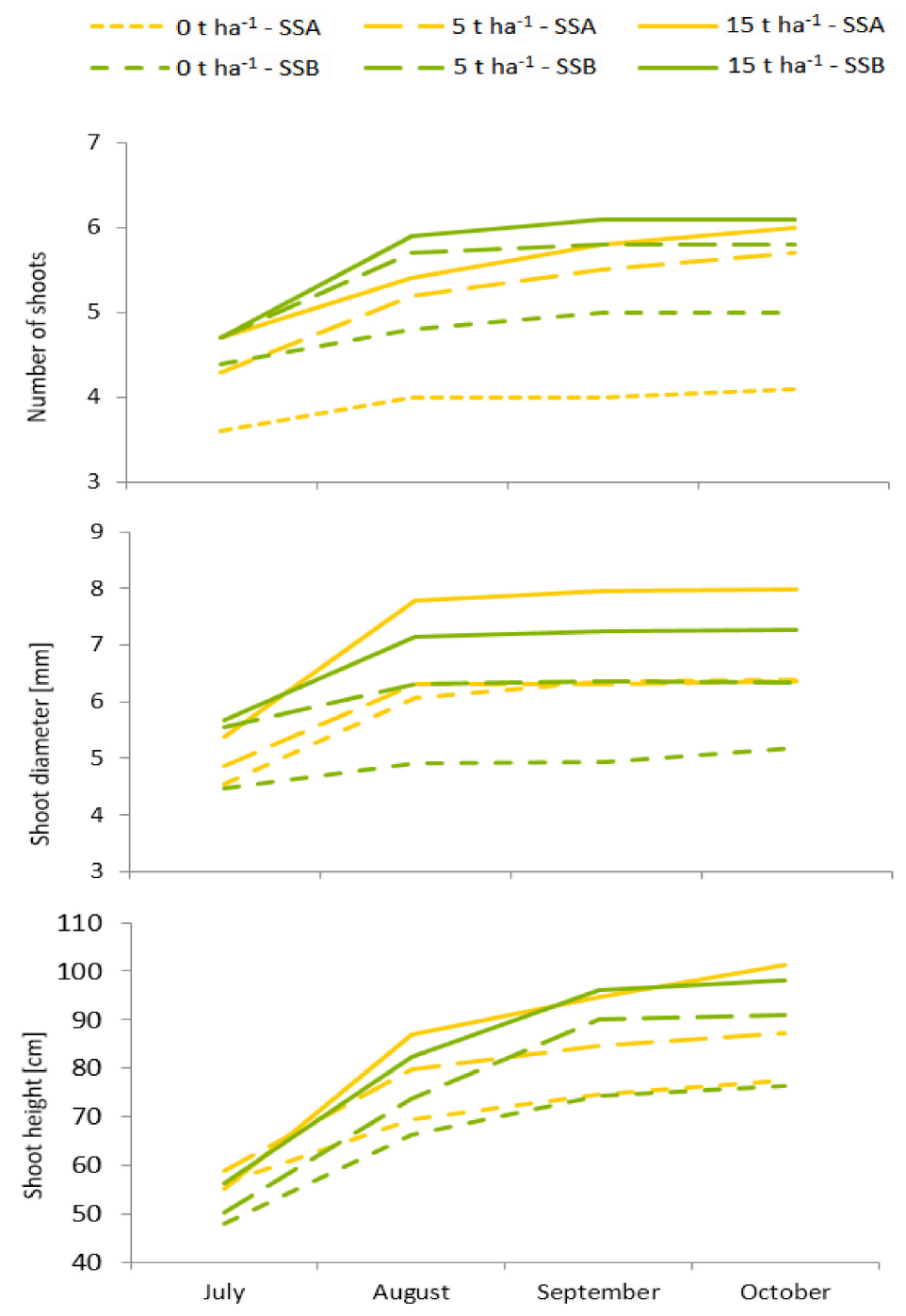

Figure 2. Growth parameters of giant reed (A. donax L.) plants cultivated in soil supplemented with sewage sludge (SS) samples in doses of 5 and $15 \mathrm{tha}^{-1}$ measured during the vegetation season. Control treatment $\left(0 \mathrm{t} \mathrm{ha}^{-1}\right.$ of SSA or SSB) represents plants cultivated in the soil without the addition of SS. 
These measurements demonstrated that a core time of the growth of giant reed plants in the given conditions was situated in the warm part of the vegetation season. Markidis et al. [30] also concluded that the rapid growth of giant reed plants was observed after shoot emergence up to the beginning of August and that in the next months the height of the shoots increased more slowly. In our experiments, shoot height increased rapidly from the planting time to the first control date (July) in all variants, at which point all treatments showed uniformity in height. From this period on, the differences among treatment groups in this indicator were observed with respect to nutrient supply. It was found that the shoot height of the control group reached the lowest values in comparison with the plants treated with SS samples. In the vegetation season of 2015, the decrease in the growth rate of shoots was demonstrated earlier because of the lower air temperature at the end of the vegetation season. In the previous season, in 2014, the plants were able to continue growing for a longer time regardless of the nutrient supply. Shoot thickening described the time dependence of the increasing shoot height. Increments of this growth parameter were observed up to the second control date (August), and from this time on the increase in shoot diameter was negligible.

\subsection{Evaluation of Growth Parameters and Biomass Yield at the End of the Vegetation Season}

From the results showed in Figure 3, it is evident that the addition of SS into arable soil positively affected all measured growth parameters. The final number of shoots was significantly increased for the application of both SS and applied doses in comparison with the control treatment without the addition of SS. The application of the higher dose of $15 \mathrm{tha}^{-1}$ in both cases significantly enhanced the shoot diameter. However, for this parameter, statistically significant differences between SSA and SSB were measured (Table 4). The final shoot height and the weight of the shoot biomass were gradually increased with the dose of SS (Figures 3 and 4A). From the point of view of shoot biomass, statistically significant differences were observed among the control, lower and higher dose of SSA or SSB. In the case of SSB, there was a greater biomass increase between the control and the dose of $5 \mathrm{t} \mathrm{ha}^{-1}$ (the biomass production was $2 \times$ higher) in comparison with the SSA (1.2 $\times$ ). A further increase of the dose of SS $\left(15 \mathrm{t} \mathrm{ha}^{-1}\right)$ led to a similar increase of the biomass yield for both SSA and SSB (1.5 $\times$ or $1.4 \times$, respectively).

Basic nitrogen use efficiency (NUE), which describes a conversion of SS nitrogen into the harvested dry matter, showed only small differences between experimental years. Dry matter production reached 54.94 and $57.87 \mathrm{~kg}$ per $1 \mathrm{~kg}$ of SS nitrogen when $5 \mathrm{t} \mathrm{ha}^{-1}$ of SSA or SSB were applied, respectively. With the higher dose of SS, the NUE decreased to 27.56 and 26.87. The agronomic efficiency of applied SS nitrogen $\left(\mathrm{AE}_{\mathrm{N}}\right)$ also involves the difference between fertilized and unfertilized treatments. During the monitored period, this indicator showed an average increment in dry matter of $18.60 \mathrm{~kg}$ per $\mathrm{kg}$ of applied $\mathrm{N}$ in the case of $5 \mathrm{tha}^{-1}$ of SS. The additional intensification of $\mathrm{N}$ inputs via $15 \mathrm{tha}^{-1}$ of SS did not cause this value to increase. On the contrary, a slight decrease of agronomic efficiency was recorded (14.61 kg of dry matter per kg of applied N). Cano-Ruiz et al. [29] also observed a decrease in $\mathrm{AE}_{\mathrm{N}}$ values when the dose of $\mathrm{N}$ for giant reed cultivation was elevated from 60 to $120 \mathrm{~kg} \mathrm{ha}^{-1}$. These parameters suggest that it could be effective to grow A. donax in conditions of low available $\mathrm{N}$ sources because the conversion of the $\mathrm{N}$ supply into dry matter decreases with an additional intensification of $\mathrm{N}$ inputs.

Table 4. $P$ values obtained from a two-way ANOVA for the dose of SS: 0,5 and $15 \mathrm{t} \mathrm{ha}^{-1}$ and the type of SS: SSA and SSB as factors. Statistically significant differences at $\alpha=0.05$ are highlighted in bold font.

\begin{tabular}{ccccc}
\hline \multirow{2}{*}{ Factor } & \multicolumn{3}{c}{$\boldsymbol{P}$ Values; Two-Way ANOVA } \\
\cline { 2 - 5 } & Weight of Biomass & No. of Shoots & Height of Shoot & Shoot Diameter \\
\hline Dose of SS & 0.0000 & 0.0001 & 0.0003 & 0.0000 \\
Type of SS & 0.0834 & 0.2832 & 0.3588 & 0.0002 \\
Interaction & 0.0009 & 0.4929 & 0.4987 & 0.5827 \\
\hline
\end{tabular}



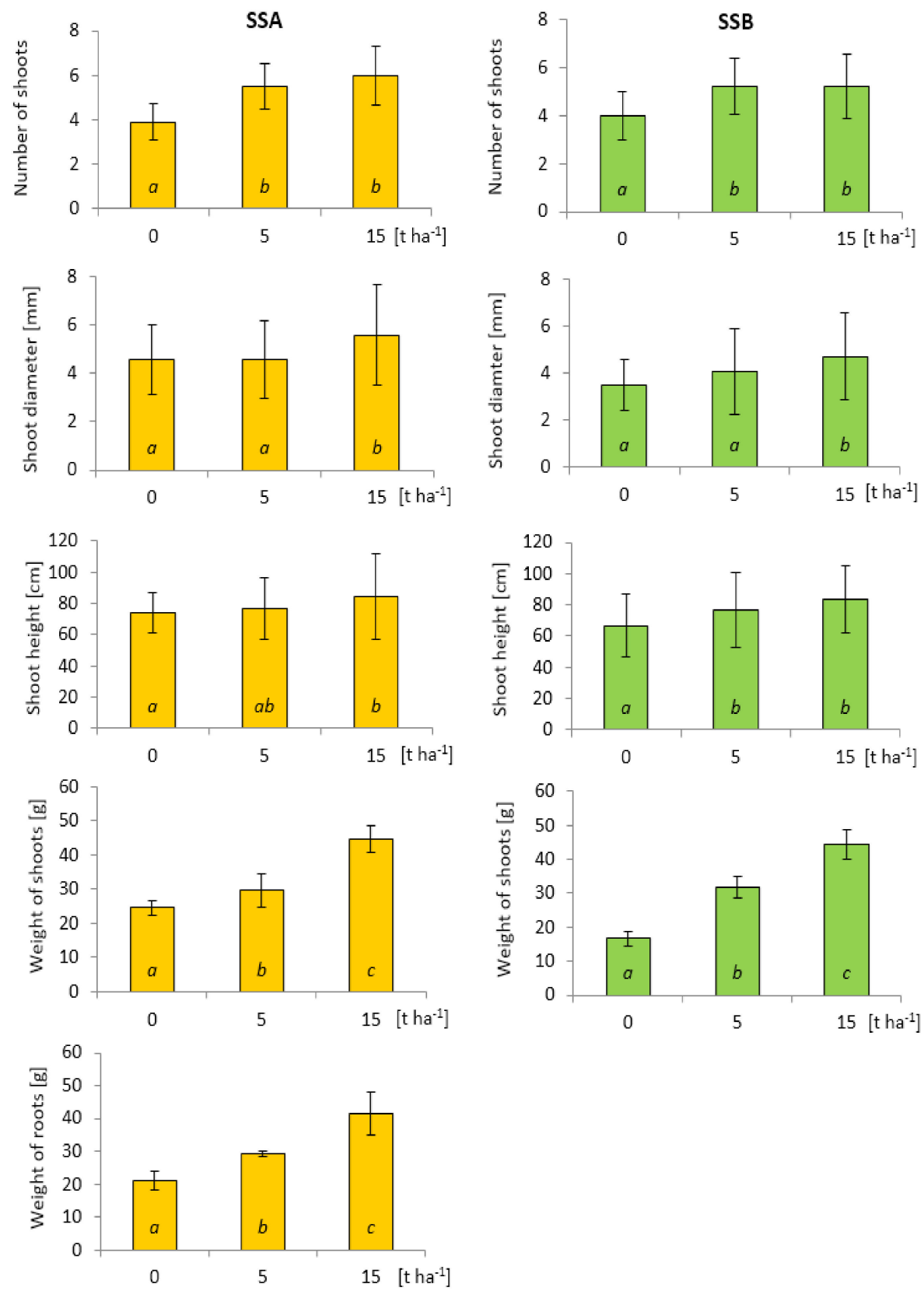

Figure 3. Growth parameters and the weight of the shoot and root biomass per plant of giant reed (A. donax L.) cultivated in a soil supplemented with sewage sludge samples (SSA-yellow columns, SSB-green columns) in doses of $5,15 \mathrm{tha}^{-1}$ and control treatment $\left(0 \mathrm{t} \mathrm{ha}^{-1}\right)$, measured at the end of the growing season. The errors of the mean values are expressed as standard deviation $( \pm S D)$. Different letters indicate statistically significant differences calculated by an LSD test $(\alpha=0.05)$.

The obtained results confirmed our hypothesis that SS could be an efficient soil additive, significantly improving the biomass yield of the energy plant $A$. donax. This is in agreement with the previously published findings. A positive effect of SS as a soil amendment on the plant characteristics and biomass yield of other energy plants from the Poaceae family was described by the research group around Kołodziej and Antonkiewicz [19-21]. They observed a significant impact of the application of SS (10-60 tha ${ }^{-1}$ ) on plant height, the number of leaves and the stems' diameter and dry weight of three cultivars of sweet sorghum [19]. All these parameters, as well as the uptake of macronutrients, were enhanced along with the increasing dose of applied SS, reaching the maximum with the application of $60 \mathrm{tha}^{-1}$ of SS. Although the yield of dry biomass increased from $7.4 \mathrm{tha}^{-1}$ 
up to $9.6 \mathrm{tha}^{-1}$, no statistically significant differences among SS doses were observed. All measured parameters were also significantly affected by the variety and the year of cultivation. In the experiments with Miscanthus $\times$ giganteus [20,21], they found that the addition of 20 tons of SS per ha supported the highest increase in the yield of biomass and its energy value. However, the most effective macronutrient recovery from SS was measured for the dose of $10 \mathrm{tha}^{-1}$. Most of the growth parameters of miscanthus grass (plant height, number of leaves and stems, and the stems' diameter) increased significantly up to the highest dose of SS $\left(60 \mathrm{tha}^{-1}\right)$ [20]. For another energy plant, reed canary grass [21], the highest yield (the significant increase from 5.3 to 13.4 tons of dry matter per ha) and the highest macronutrient uptake were observed when $40 \mathrm{t} \mathrm{ha}^{-1}$ of SS was applied. Corn (Zea mays L.) is grown for grain production but is also considered an energy plant. Vaca et al. [12] compared the effect of SS, SS compost and inorganic fertilizer (NPK in 15:75:30 ratio) on the plant growth and grain yields and observed that the plant height, number of leaves and corn cobs, and the yields of grain per ha were higher in the case of soil amended with SS in the dose of $18 \mathrm{tha}^{-1}$ and an equal dose of SS compost compared with the soil fertilized with an inorganic fertilizer. In the pot experiments with Sida hermaphrodita, Wierbowska et al. [17] observed that the yield of aboveground biomass increased from $20.15 \mathrm{tha}^{-1}$ up to $53.9 \mathrm{t} \mathrm{ha}^{-1}$ by using SS in a dose corresponding to $0.15 \mathrm{~g}$ of $\mathrm{N}$ and $\mathrm{K}$ and $0.084 \mathrm{~g}$ of P per $\mathrm{kg}$ of soil substrate. In our experiment, the same increase in the biomass yield of giant reed plants $(2.76 \times)$ was measured after the application of $15 \mathrm{t} \mathrm{ha}^{-1}$ of SSB, corresponding to $0.23 \mathrm{~g}$ of N, $0.018 \mathrm{~g}$ of $\mathrm{K}$ and $0.11 \mathrm{~g}$ of P per $\mathrm{kg}$ of soil.

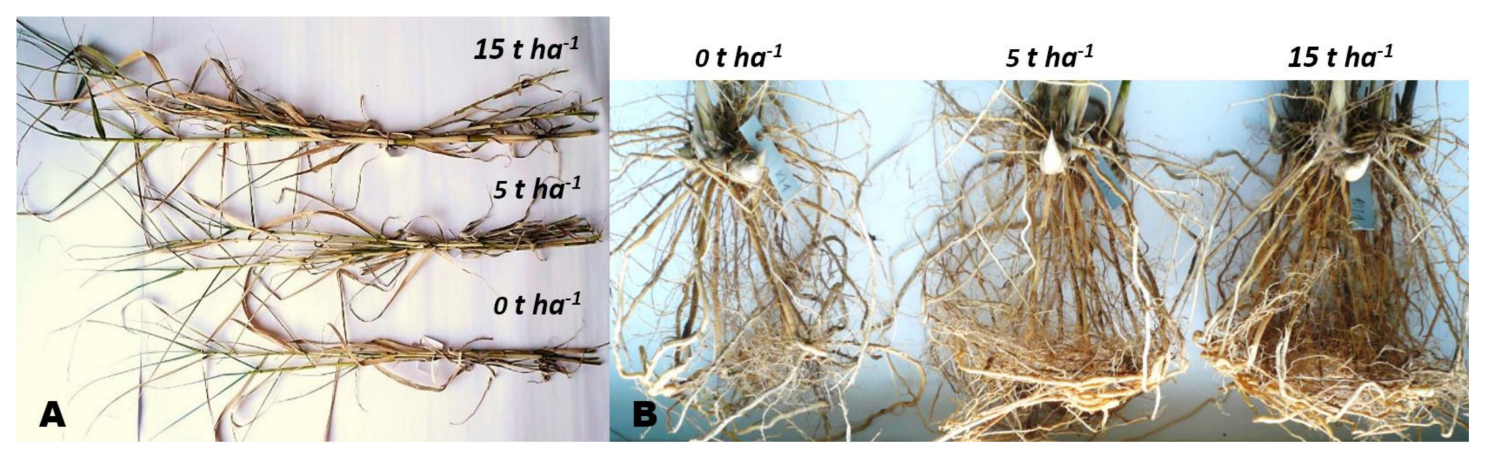

Figure 4. Shoot (A) and root (B) biomass of giant reed (A. donax L.) plants cultivated in the soil supplemented with SSA in doses of 5 and $15 \mathrm{t} \mathrm{ha}^{-1}$, control variant $\left(0 \mathrm{tha}^{-1}\right)$ without SS supplement.

Our experiment also showed that the root biomass increased alongside the aboveground biomass. The weight of the root biomass was measured for SSA only, and statistically significant differences were observed among the control, the lower and the higher dose of SS (Figures 3 and 4B). The ratio of root-to-shoot biomass was $46 \% / 54 \%$ for the control variant, and this parameter was not significantly changed for the SS treatments (50\% or $48 \%$ proportion of root biomass, respectively). Moreover, the increases in shoot and root weight after the application of SS were highly correlated $(P=0.012$, $r=0.79$ ). Organic soil amendments promote plant growth not only directly, by improving the soil fertility due to macro- and microelement content, but also indirectly, by enhancing the biological properties of soil through the stimulation of microbial growth in the rhizosphere [8]. The plant roots release a wide range of chemicals in the form of root exudates, which determines the plant-microbe interaction in the rhizosphere [31]. At the same time, various factors impact the composition of root exudates, like the plant's species and developmental stage or various environmental factors, such as $\mathrm{pH}$, temperature, soil type, soil moisture or PTE content, etc. [32]. We observed some indications of a plant-microbial interaction in our previously published parallel experiments, with the same doses of SSA added to the soil and monitoring the dynamics of the microbial communities in the A. donax rhizosphere. In these experiments, we found that the total microbial biomass statistically increased with the addition of SS [22]. Likewise, the alpha diversity of fungal rhizosphere communities was significantly increased in sludge-added soils, and more varied fungal taxa were detected in the soil sample with SS when compared to the control treatment [23]. Enhanced biological parameters of the 
soil were also confirmed by Kołodziej et al. [19] by measuring the soil enzymes as markers of biological fertility during the cultivation of sweet sorghum in an SS-amended soil. The addition of SS to the agricultural soil induced an increase in microbial enzymatic activity.

Giant reed plants are adaptable to different growing conditions. They can tolerate drought and require a low amount of nutrients [33], but irrigation and fertilization increase the yield of the biomass. As this species is not grown for food purposes, SS can represent a suitable fertilizer, containing remarkable amounts of low-cost nutrients, macroelements (N, P or K) and microelements ( $\mathrm{Zn}$ or $\mathrm{Cu}$ ). Both types of SS used in our experiment were especially rich in phosphorus and nitrogen, the building components of the plants' organic matter. Energy crops or plants grown for biomass can effectively benefit from $\mathrm{N}$ fertilization that increases aboveground biomass growth [34] and phosphorus that is responsible for root development and increases the height and strength of shoots and shoot dry biomass production [35]. Nitrogen, phosphorus and potassium, which supports water uptake into the plants, are the three main macroelements directly affecting plant growth. The total amounts of $\mathrm{N}$ and $\mathrm{P}$ added to the soil by the application of SSA $(0.54 \mathrm{~g}$ of $\mathrm{N}$ and $0.28 \mathrm{~g}$ of $\mathrm{P})$ or SSB $(0.55 \mathrm{~g}$ of $\mathrm{N}$ and $0.26 \mathrm{~g}$ of $\mathrm{P})$ per pot for the dose of $5 \mathrm{t} \mathrm{ha}^{-1}$ were similar in both SS samples. But the content of other nutrients was different, especially in the portion of potassium and carbon which was higher in SSA. On the other hand, calcium and magnesium were higher in the case of SSB. Despite the different content of some nutrients, PTEs and slightly different weather conditions in 2014 and 2015, significant differences between the effect of SSA and SSB were measured only for the shoot diameter, as was confirmed by a two-way ANOVA (Table 4). The soil used in our experiments was very low in nitrogen. Depending on the dose of SS applied into the soil, the total content of $\mathrm{N}$ increased from $0.096 \%$ to $0.103 \%$ (i.e., $1.1 \times$ ) or $0.118 \%(1.2 \times)$, respectively. From the comparison of the studied samples of SS with the samples characterized in other research or review works, it can be concluded that the SS samples used in this work showed a lower proportion of $\mathrm{N}$ than the average values of $4-7 \%[36,37]$. The application of SS also had the positive effect of enhancing the content of $P$ in the soil, which increased by $1.4 \times$ or $2.1 \times$, respectively. The recovery of phosphorus from wastes helps to avoid its depletion and enhances the sustainability of its reserves, that are limited worldwide. The increase in biomass production was similar using both types of SS, probably due to the same content of both of these elements (N and P), which directly affect plant growth.

It is known that perennial rhizomatous plants effectively recycle nutrients through their remobilization from aboveground to belowground tissues at the end of the growing season, and that they store the nutrients in the rhizomes during the winter $[38,39]$. This fact suggests that the application of SS into the soil in the case of these species can bring benefits several growing seasons after the first application, during culture establishment. This was demonstrated in the experiment of Kołodziej et al. [20], where SS was applied only once before planting Miscanthus $\times$ giganteus, and where the positive effect of its application on the biomass yield was observed in the following five years. We expect the same effect in the case of giant reed plants. However, this should be confirmed in a long-term field experiment. In our experiments, lower doses of SS ( 5 and $15 \mathrm{tha}^{-1}$ ) were studied in comparison to the above-mentioned papers [19-21]. Although a higher dose of SS could further increase the yield of biomass, the doses of SS chosen for our experiment follow the Act No. 188/2003 (Slovak Republic), that allows for the application of sewage sludge to the agricultural soil in doses which do not exceed a total of 15 tons per hectare in five consecutive years. According to the above-mentioned act, the application of SS is forbidden when the groundwater level is not deeper than $0.5 \mathrm{~m}$ or the soil is waterlogged. A strict compliance with the rules of SS application together with adequate dosing allow for the reduction of nitrogen leaching, which may be a problem when high doses of $\mathrm{N}$ are applied. Council Directive No. 91/66/EEC allows for the fertilization of the soil according to the crops' foreseeable nitrogen requirements. When using organic manures (including sewage sludge) as a soil amendment, doses containing a maximum of $170 \mathrm{~kg}$ or $210 \mathrm{~kg}$ (for the first four-year action) of $\mathrm{N}$ are allowed. In the case of our SS samples, the dose of $\mathrm{N}$ applied to 1 ha of agricultural soil by using $5 \mathrm{t} \mathrm{ha}^{-1}$ of SS would be $175 \mathrm{~kg}$. 


\subsection{Metals Accumulation and Distribution in Plants}

As previously mentioned, the samples of SS did not contain undesirable PTEs-such as As, Cd, $\mathrm{Cr}, \mathrm{Pb}$ or $\mathrm{Ni}$-in concentrations exceeding the levels permitted by the Acts of the Slovak Republic or the directives of the EU. However, $\mathrm{X}$-ray fluorescence spectrometry revealed that the applied samples of SS showed a significant presence of $\mathrm{Zn}$ and $\mathrm{Cu}$ (Table 1). Due to this fact, the accumulation of the above-mentioned PTEs by giant reed plants and their distribution between roots and shoots were assessed.

Firstly, it was found that after the application of 5 or $15 \mathrm{t} \mathrm{ha}^{-1}$ of SSA the amounts of $\mathrm{Zn}$ and $\mathrm{Cu}$ in the soil increased from 62.3 to $76.7 \mathrm{mg} \mathrm{kg}^{-1}$ and from 11.7 to $14.4 \mathrm{mg} \mathrm{kg}^{-1}$, respectively. Nevertheless, these values were lower than the limits permitted by the Act No. 188/2003 (Slovak Republic).

From Figure 5, it is evident that the application of SSA into the soil caused a significant increase of $\mathrm{Zn}$ and $\mathrm{Cu}$ accumulation in the shoots of giant reed. The gradual increase of the dose of SSA led to a $1.8 \times$ and $1.9 \times$ increase in the accumulation of $\mathrm{Zn}$ and $\mathrm{Cu}$ in the aboveground parts of the plants, respectively. In the case of the roots, this phenomenon was not statistically significant, except for the dose of $5 \mathrm{tha}^{-1}$ applied into the soil. The accumulation of $\mathrm{Zn}$ and $\mathrm{Cu}$ in the roots of giant reed plants was approx. $1.3 \times$ higher for the mentioned dose of $5 \mathrm{t} \mathrm{ha}^{-1}$ in comparison with the control treatment. In the experiment with sorghum [19], the index of $\mathrm{Zn}$ bioaccumulation increased 1.3 $\times$ after the application of SS in a dose of $60 \mathrm{tha}^{-1}$, but for $\mathrm{Cu}$ no significant increase was observed.

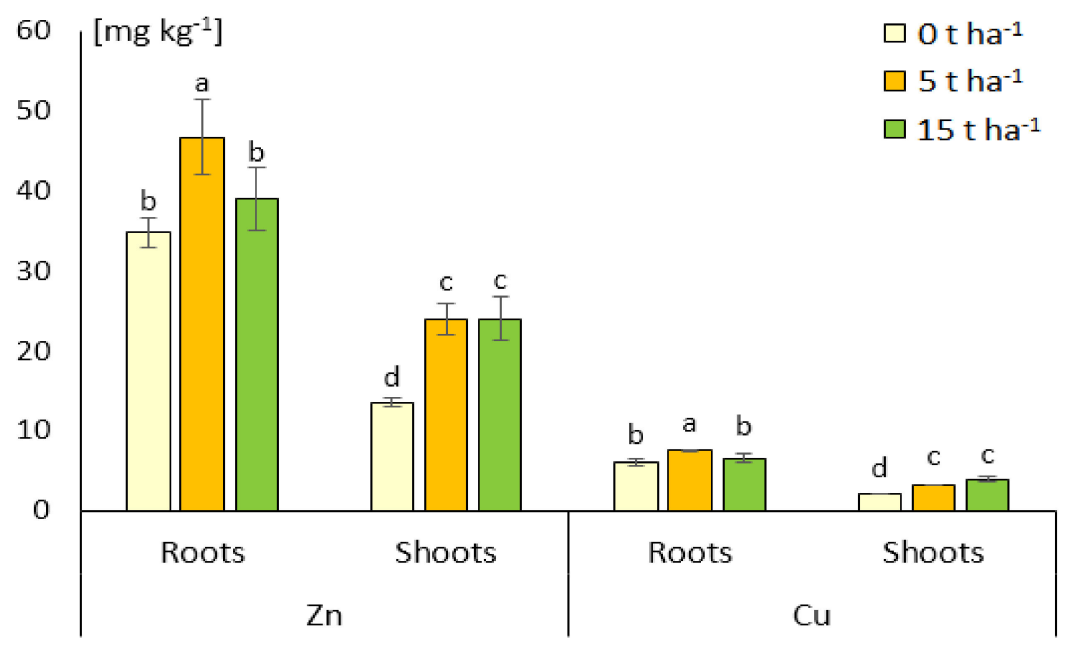

Figure 5. Accumulation of $\mathrm{Cu}$ and $\mathrm{Zn}$ in giant reed (A. donax L.) plants cultivated in a soil supplemented with sewage sludge SSA in doses of 5 and $15 \mathrm{tha}^{-1}$. The control variant $\left(0 \mathrm{tha} \mathrm{h}^{-1}\right)$ represents plants cultivated in soil without the addition of SS, and the errors of the mean values are expressed as standard deviation $( \pm S D)$. Different letters indicate statistically significant differences calculated by an LSD test $(\alpha=0.05)$.

Generally, it can be said that the accumulation of both metals, $\mathrm{Zn}$ and $\mathrm{Cu}$, was lower in the shoots than in the roots. The translocation of $\mathrm{Zn}$ described by the ratio of metal concentration in the shoots $\left(\mathrm{mg} \mathrm{kg}^{-1}\right.$; d.w.) to the metal concentration in the roots $\left(\mathrm{mg} \mathrm{kg}^{-1}\right.$; d.w.) increased from 0.39 , the value calculated for the control treatment, to 0.52 , the value determined for the application of $15 \mathrm{t} \mathrm{ha}^{-1}$ of SSA. The translocation of $\mathrm{Cu}$ from 0.35 to 0.53 was enhanced in this comparison. From the environmental point of view, it is also important to calculate the transfer factor (TF) defined as the ratio of metal concentration in the plant's biomass ( $\mathrm{mg} \mathrm{kg}^{-1}$; d.w.) to that in the soil $\left(\mathrm{mg} \mathrm{kg}^{-1}\right.$; d.w.). The TF for $\mathrm{Zn}$ and the control experiment reached 0.56 and 0.22 , the values calculated for the roots and the shoots, respectively. In the case of $\mathrm{Cu}$, these values were 0.52 and 0.18 . The application of SS caused the increase of the TF values calculated for the shoots by approx. $1.7 \times$ and $1.5 \times$ for $\mathrm{Zn}$ and $\mathrm{Cu}$, respectively. This effect was observed, to a lesser extent, in the roots. Based on these results, it can be concluded 
that $\mathrm{Zn}$ was more accumulated by giant reed plants and translocated into the aboveground parts than $\mathrm{Cu}$. This fact can be explained by the higher biological availability of $\mathrm{Zn}$ in the soil. An individual analysis showed that the extractability of $\mathrm{Zn}$ from the soil significantly increased, with the dose of SSA from $5.0 \%$ of extractable $\mathrm{Zn}$, to $23 \%$, as determined by AAS in the extracts obtained with Mehlich III solutions. The extractability of $\mathrm{Cu}$ was higher ( $24.4 \%$ for the soil without the application of SS), but the effect of the application of SSA into the soil on the portion of available $\mathrm{Cu}$ was less significant.

Elloumi et al. [40] studied the effect of SS application $(2.5 \%, 5 \%$ and $7.5 \%)$ on the growth of tomato (Solanum lycopersicum L. cv. Rio Grande) seedlings. They also found that the addition of SS to the soil increased the extractability of PTEs ( $\mathrm{Zn}, \mathrm{Cu}$ and $\mathrm{Cr}$ ). Their results showed that $\mathrm{Zn}$ had the highest capacity for transferring from the soil into plants. Low metal translocation was observed from the roots to the leaves. The $7.5 \%$ SS dose decreased the biomass production and caused a decline in the chlorophyll content and stomatal conductance. Therefore, they argued that the use of $2.5 \%$ and $5 \%$ doses of SS in agriculture would be an efficient and cost-effective method to restore the fertility of soils and an environment-friendly solution for disposal problems. Similar results were also observed in the work of Belhaj et al. [41], where the effect of sewage sludge fertilizer on PTE accumulation and the consequent responses of sunflower (Helianthus annuus L.) plants were assessed.

\section{Conclusions}

The results of our experiments suggest that sewage sludge in the tested doses ( 5 and $15 \mathrm{tha}^{-1}$ ) could be effectively used for the fertilization of energy crops or plants grown for biomass production. The positive effect of the application of both studied types of SS was confirmed for the growth of giant reed (A. donax L.) plants, and it was characterized by growth parameters such as shoot height, number of shoots, shoot diameter and the yield of dry biomass. Significant differences between the effect of both studied samples of SS, which were characterized by a similar content of nitrogen and phosphorus, were described only for the shoot diameter. Even at the highest applied dose of SS permitted by the Act No. 188/2003 in the Slovak Republic or EU directives-i.e., $15 \mathrm{t} \mathrm{ha}^{-1}$ - the negative or toxic effects of SS amendment on plant growth were not observed. The analyses that were conducted showed that the samples of SS did not contain undesirable toxic metals ( $\mathrm{As}, \mathrm{Cd}, \mathrm{Cr}, \mathrm{Pb}$ or Ni) in concentrations which exceeded the limits permitted by the above-mentioned Act, but they were rich in $\mathrm{Zn}$ and $\mathrm{Cu}$. The addition of SS into the soil had a positive effect on the amount of these metals in the soil and on their biological availability. The increased concentration of $\mathrm{Zn}$ and $\mathrm{Cu}$ in the soil due to the SS amendment led to increases in the shoot and root concentrations of $\mathrm{Zn}$ and $\mathrm{Cu}$ as compared to those grown on the unamended soil, wherein the accumulation of both metals was lower in the shoots than in the roots. The values of the transfer factor-defined as the ratio of metal concentration in plant biomass $\left(\mathrm{mg} \mathrm{kg}^{-1}\right.$; d.w.) to that in the soil $\left(\mathrm{mg} \mathrm{kg}^{-1}\right.$; d.w.), and calculated for $\mathrm{Zn}$ and $\mathrm{Cu}$, or root and shoot biomass-were significantly increased by the application of SS.

The fertilization of soils by SS has proved to be a suitable way of enriching nutrient-poor or degraded soils that cannot be used for agricultural purposes. Combining this approach with the cultivation of energy crops increases the efficiency and value of such a process. Moreover, the application of these experiments to phytoremediation methods is a major challenge for scientists and practice.

Author Contributions: Conceptualization, M.G.; methodology, M.G., J.G. and M.H. (Miroslav Horník); statistics, M.G. and M.H. (Miroslav Horník).; analyses, A.J., J.G. and K.H.; writing-original draft preparation, M.G., M.H. (Miroslav Horník) and K.H.; writing - review and editing, K.O. and M.H. (Martina Hudcovicová); project administration, M.H. All authors have read and agreed to the published version of the manuscript.

Funding: This work was supported by the Slovak Research and Development Agency under the contract no. APVV-15-0098.

Conflicts of Interest: The authors declare no conflicts of interest. 


\section{References}

1. Kumar, V.; Chopra, A.K.; Kumar, A. A review on sewage sludge (Biosolids) a resource for sustainable agriculture. Arch. Agric. Environ. Sci. 2017, 2, 340-347. [CrossRef]

2. Eurostat. Available online: https://ec.europa.eu/eurostat (accessed on 4 January 2020).

3. Hudcová, H.; Vymazal, J.; Rozkošný, M. Present restrictions of sewage sludge application in agriculture within the European Union. Soil Water Res. 2019, 14, 104-120. [CrossRef]

4. Shaddel, S.; Bakhtiary-Davijany, H.; Kabbe, C.; Dadgar, F.; Østerhus, S.W. Sustainable sewage sludge management: From current practices to emerging nutrient recovery technologies. Sustainability 2019, 11, 3435. [CrossRef]

5. Suschka, J.; Grübel, K. Nitrogen in the process of waste activated sludge anaerobic digestion. Arch. Environ. Prot. 2014, 40, 123-136. [CrossRef]

6. Houben, D.; Michel, E.; Nobile, C.; Lambers, H.; Kandeler, E.; Faucon, M.P. Response of phosphorus dynamics to sewage sludge application in an agroecosystem in northern France. Appl. Soil Ecol. 2019, 137, 178-186. [CrossRef]

7. Kominko, H.; Gorazda, K.; Wzorek, Z. The Possibility of organo-mineral fertilizer production from sewage sludge. Waste Biomass Valori. 2017, 8, 1781-1791. [CrossRef]

8. Urra, J.; Alkorta, I.; Garbisu, C. Potential Benefits and Risks for Soil Health Derived From the Use of Organic Amendments in Agriculture. Agronomy 2019, 9, 542. [CrossRef]

9. $\mathrm{Xu}, \mathrm{G}$. Analysis of Sewage sludge Recovery System in EU in Perspectives of Nutrients and Energy Recovery Efficiency, and Environmental Impacts. Master's Thesis, Norwegian University of Science and Technology, Trondheim, Norway, 2014.

10. Zubala, T.; Patro, M.; Boguta, P. Variability of zinc, copper and lead contents in sludge of the municipal stormwater treatment plant. Environ. Sci. Pollut. Res. 2017, 24, 17145-17152. [CrossRef]

11. Zennegg, M.; Munoz, M.; Schmid, P.; Gerecke, A.C. Temporal trends of persistent organic pollutants in digested sewage sludge (1993-2012). Environ. Int. 2013, 60, 202-208. [CrossRef]

12. Vaca, R.; Lugo, J.; Martínez, R.; Esteller, M.V.; Zavaleta, H. Effects of sewage sludge and sewage sludge compost amendment on soil properties and Zea mays L. plants (heavy metals, quality and productivity). Rev. Int. Contam. Ambie. 2011, 27, 303-311.

13. Dar, M.I.; Naikoo, M.I.; Khan, F.A.; Green, I.D. Assessing the Feasibility of Sewage Sludge Applications for the Cultivation of Brassica Juncea L.: Metal Accumulation, Growth, Biochemical and Yield Responses. Environ. Sci. Renew. Res. 2018, 1, 104. [CrossRef]

14. Kumar, V.; Chopra, A.K. Agronomical performance of high yielding cultivar of eggplant (Solanum melongena L.) grown in sewage sludge amended soil. Res. Agric. 2016, 1, 1-24. [CrossRef]

15. Shahbazi, F.; Ghasemi, S.; Sodaiezadeh, H.; Ayaseh, K.; Zahani-Ahmadmahmoodi, R. The effect of sewage sludge on heavy metal concentrations in wheat plant (Triticum aestivum L.). Environ. Sci. Pollut. Res. Int. 2017, 24, 15634-15644. [CrossRef] [PubMed]

16. Lag-Brotons, A.; Gómez, I.; Navarro-Pedreño, J.; Mayoral, A.M.; Curt, M.D. Sewage sludge compost use in bioenergy production- A case study on the effects on Cynara cardunculus L energy crop. J. Clean. Prod. 2014, 79, 32-40. [CrossRef]

17. Wierzbowska, J.; Sienkiewicz, S.; Krzebietke, S.; Sternik, P. Sewage sludge as source of nitrogen and phosphorus for virginia fanpetals. Bulg. J. Agri. Sci. 2016, 22, 722-727.

18. Kubátová, P.; Hejcman, M.; Száková, J.; Vondráčková, S.; Tlustoš, P. Effects of Sewage sludge application on biomass production and concentrations of $\mathrm{Cd}, \mathrm{Pb}$ and $\mathrm{Zn}$ in shoots of Salix and Populus clones: Improvement of phytoremediation efficiency in contaminated soils. Bioenerg. Res. 2016, 9, 809-819. [CrossRef]

19. Kołodziej, B.; Antonkiewicz, J.; Stachyra, M.; Bielińska, E.J.; Wiśniewski, J.; Luchowska, K.; Kwiatkowski, C. Use of sewage sludge in bioenergy production-A case study on the effects on sorghum biomass production. Eur. J. Agron. 2015, 69, 63-74. [CrossRef]

20. Kołodziej, B.; Antonkiewicz, J.; Sugier, D. Miscanthus $\times$ giganteus as a biomass feedstock grown on municipal sewage sludge. Ind. Crops Prod. 2016, 81, 72-82. [CrossRef]

21. Antonkiewicz, J.; Kołodziej, B.; Bielińska, E.J.; Popławska, A. The possibility of using sewage sludge for energy crop cultivation exemplified by reed canary grass and giant miscanthus. Soil Sci. Ann. 2019, 70, $21-33$. [CrossRef] 
22. Ondreičková, K.; Gubišová, M.; Gubiš, J.; Klčová, L.; Horník, M. Rhizosphere bacterial communities of Arundo donax grown in soil fertilised with sewage sludge and agricultural by-products. Agriculture 2019, 65, 37-41. [CrossRef]

23. Ondreičková, K.; Gubišová, M.; Piliarová, M.; Horník, M.; Matušinský, P.; Gubiš, J.; Klčová, L.; Hudcovicová, M.; Kraic, J. Responses of rhizosphere fungal communities to the sewage sludge application into the soil. Microorganisms 2019, 7, 505. [CrossRef] [PubMed]

24. Alshaal, T.; Elhawat, N.; Domokos-Szabolcsy, É.; Kátai, J.; Márton, L.; Czako, M.; El-Ramady, H.; Fári, M.G. Giant reed (Arundo donax L.): A green technology for clean environment. In Phytoremediation: Management of Environmental Contaminants, 1st ed.; Ansari, A.A., Gill, S.S., Gill, R., Lanza, G.R., Newman, L., Eds.; Springer International Publishing: Basel, Switzerland, 2015; Volume 1, pp. 3-20. [CrossRef]

25. Dürešová, Z.; Šuňovská, A.; Horník, M.; Pipíška, M.; Gubišová, M.; Gubiš, J.; Hostin, S. Rhizofiltration potential of Arundo donax for cadmium and zinc removal from contaminated wastewater. Chem. Pap. 2014, 68, 1452-1462. [CrossRef]

26. Gubišová, M.; Čičková, M.; Klčová, L.; Gubiš, J. In vitro tillering-An effective way to multiply high-biomass plant Arundo donax. Ind. Crops Prod. 2016, 81, 123-128. [CrossRef]

27. Spencer, D.F.; Ksander, G. Estimating Arundo donax ramet recruitment using degree-day based equations. Aquat. Bot. 2006, 85, 282-288. [CrossRef]

28. Foulkes, M.J.; Murchie, E.H. Optimizing Canopy Physiology Traits to Improve the Nutrient Utilization Efficiency of Crops. In The Molecular and Physiological Basis of Nutrient Use Efficiency in Crops, 1st ed.; Hawkesford, M.J., Barraclough, P., Eds.; John Wiley \& Sons: Chichester, West Sussex, UK, 2011; pp. 63-82. [CrossRef]

29. Cano-Ruiz, J.; Sanz, M.; Curt, M.D.; Plaza, A.; Lobo, M.C.; Maur, P.V. Fertigation of Arundo donax L. with different nitrogen rates for biomass production. Biomass Bioenergy 2020, 133, 105451. [CrossRef]

30. Mardikis, M.; Christou, M.; Alexopoulou, E. Arundo donax population screening in Greece. In Proceedings of the World Conference and Exhibition on Biomass for Energy and Industry, Sevilla, Spain, 5-9 June 2000; Kyritsis, S., Beenackers, A.A.C.M., Helm, P., Grassi, A., Charamonti, D., Eds.; James \& James Science Publisher: London, UK, 2001; pp. 1626-1629.

31. Sharma, A.; Verma, R.K. Root-Microbe Interactions: Understanding and Exploitation of Microbiome. In Root Biology; Giri, B., Prasad, R., Varma, A., Eds.; Springer: Cham, Switzerland, 2018; Volume 52, pp. 323-339. [CrossRef]

32. Badri, D.V.; Vivanco, J.M. Regulation and function of root exudates. Plant Cell Environ. 2009, 32, 666-681. [CrossRef]

33. Pilu, R.; Bucci, A.; Badone, F.C.; Landoni, M. Giant reed (Arundo donax L.): A weed plant or a promising energy crop? Afr. J. Biotech. 2012, 11, 9163-9174. [CrossRef]

34. Tong, Z.; Quan, G.; Wan, L.; He, F.; Li, X. The Effect of Fertilizers on Biomass and Biodiversity on a Semi-Arid Grassland of Northern China. Sustainability 2019, 11, 2854. [CrossRef]

35. Malhotra, H.; Sharma, S.; Pandey, R. Phosphorus Nutrition: Plant Growth in Response to Deficiency and Excess. In Plant Nutrients and Abiotic Stress Tolerance, 1st ed.; Hasanuzzaman, M., Fujita, M., Oku, H., Nahar, K., Hawrylak-Nowak, B., Eds.; Springer: Singapore, 2018; pp. 171-190. [CrossRef]

36. Rigby, H.; Clarke, B.O.; Pritchard, D.L.; Meehan, B.; Beshah, F.; Smith, S.R.; Porter, N.A. A critical review of nitrogen mineralization in biosolids-amended soil, the associated fertilizer value for crop production and potential for emissions to the environment. Sci. Total Environ. 2016, 541, 1310-1338. [CrossRef]

37. Syed-Hassan, S.S.A.; Wang, Y.; Hu, S.; Su, S.; Xiang, J. Thermochemical processing of sewage sludge to energy and fuel: Fundamentals, challenges and considerations. Renew. Sustain. Energy Rev. 2017, 80, 888-913. [CrossRef]

38. Christian, D.G.; Poulton, P.R.; Riche, A.B.; Yates, N.; Todd, A.D. The recovery over several seasons of ${ }^{15} \mathrm{~N}$-labelled fertilizer applied to Miscanthus $\times$ giganteus ranging from 1 to 3 years old. Biomass Bioenergy 2006, 30, 125-133. [CrossRef]

39. Nassi o Di Nasso, N.; Roncucci, N.; Bonari, E. Seasonal Dynamics of Aboveground and Belowground Biomass and Nutrient Accumulation and Remobilization in Giant Reed (Arundo donax L.): A Three-Year Study on Marginal Land. BioEnergy Res. 2013, 6, 725-736. [CrossRef] 
40. Elloumi, N.; Belhaj, D.; Jerbi, B.; Zouari, M.; Kallel, M. Effects of sewage sludge on bio-accumulation of heavy metals in tomato seedlings. Span. J. Agric. Res. 2016, 14, e0807. [CrossRef]

41. Belhaj, D.; Elloumi, N.; Jerbi, B.; Zouari, M.; Abdallah, F.B.; Ayadi, H.; Kallel, M. Effects of sewage sludge fertilizer on heavy metal accumulation and consequent responses of sunflower (Helianthus annuus). Environ. Sci. Pollut. Res. 2016, 23, 20168-20177. [CrossRef] [PubMed] 